\title{
Lovenula (Neolovenula) alluaudi (Guerne and Richard, 1890) in the Canary Islands (Copepoda: Calanoida: Paradiaptominae)
}

Stygofauna of the Canary Islands, 19

\author{
Thomas E. Bowman \\ Department of Invertebrate Zoology, NHB-163, Smithsonian Institution, Washington, DC 20560, U.S.A.
}

Keywords: Copepoda, Calanoida, Lovenula, Canary Islands, stygofauna

\begin{abstract}
Lovenula (Neolovenula) alluaudi is widespread on Lanzarote, where it occurred at 22 of the 105 stations. On Fuerteventura it was found at only 2 of the 53 stations, both in the extreme northwest part of the island. It was also found in a reservoir on the south side of the small island of Alegranza. Samples collected at several hundred stations in the other Canary Islands failed to yield a single calanoid, supporting the belief that the eastern islands are fragments of the African continent that drifted to deeper waters.

Males outnumbered females in about $2 / 3$ of the samples, often heavily.
\end{abstract}

\section{Résumé}

Lovenula (Neolovenula) alluaudi est largement répandue à Lanzarote, étant trouvée à 22 des 105 stations échantillonnées. A Fuerteventura, l'espèce a été trouvée dans seulement 2 des 53 stations, les deux à l'extrémité nord-ouest de l'île. Elle a été capturée aussi dans un réservoir d'eau à la partie méridionale de la petite île Alegranza. Aucun Calanoïde n'a été trouvé dans des centaines de stations échantillonnées dans les autres îles des Canaries, ce qui fait penser que les îles orientales sont des fragments du continent africain déplacés vers des eaux plus profondes. Dans environ $2 / 3$ des échantillons, les mâles dépassent en nombre - souvent très nettement - les femelles.

\section{Introduction}

In May 1985, as part of a planned survey of the groundwater fauna of the Canary Islands, samples were taken of the groundwater on 3 of the eastern islands, Graciosa, Lanzarote, and Fuerteventura, by Jan H. Stock and Brigitte L.M. Rondé-Broekhuizen, of the Institute of Taxonomic Zoology, University of Amsterdam. Details of the collection methods and station locations are given by Stock \& Rondé-Broekhuizen (1986). The calanoid copepods from these samples were sent to me by Prof. Stock for study. One sample from Lanzarote (Sta. 85-88) has been deposited in the Smithsonian Institution (USNM 242456); the remainder has been returned to Amsterdam.

\section{Results}

A single species of calanoid was collected, Lovenula (Neolovenula) alluaudi (Guerne \& Richard, 1890). It was most common on Lanzarote, where it was taken at 22 of the 105 stations occupied. The positive stations were widely scattered over most of the island (fig. 1). All were wells or cisterns, 18 of them covered. Depths to the water surface in the wells ranged from 0.2 to $11 \mathrm{~m}$, and water depths in the wells ranged from 0.25 to $4.75 \mathrm{~m}$. Water temperatures ranged from $16.1^{\circ} \mathrm{C}$ to $27.9^{\circ} \mathrm{C}$, and measurements of conductivity were from 0.252 to 17.16 $\mathrm{mS} / \mathrm{cm}$.

On Fuerteventura $L$. (N.) alluaudi was found at only 2 of the 53 stations, both in Toston, on the northwest coast of the island. One station was the cistern of Faro, with a salinity of $1 \%$; the other was an open well near the seawater distillation plant. The salinity in the well water was $32 \%$. I 


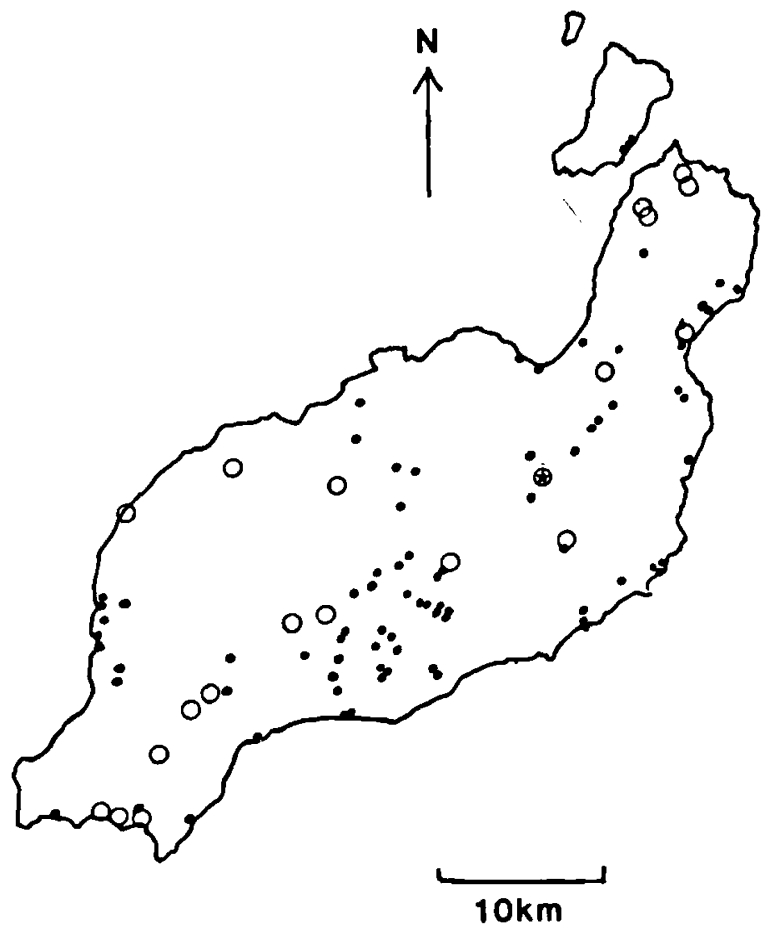

Fig. 1. Lanzarote and Graciosa showing locations of groundwater samples collected in 1985 . Open circles, samples containing Lovenula (Neolovenula) alluaudi. Solid circles, other samples. Star, type locality of $L$. (N.) alluaudi

questioned this because this was a surprisingly high salinity for a diaptomid copepod, but Prof. Stock assurred me that it was correct.

On the small island of Alegranza, which lies about $15 \mathrm{~km}$ north of Lanzarote, $L$. (N.) alluaudi was collected in January 1986 from a man-made reservoir with a rain catchment, maximum depth 2 $\mathrm{m}$, on the south side of the island. The conductivity was $2.38 \mathrm{mS} / \mathrm{cm}$.

\section{Discussion}

The distribution of $L$. (N.) alluaudi is summarized by Dussart (1967) as "relatively rare and circumMediterranean, it has been observed in the Canary Islands, Morocco, Egypt, Syria, in the Balkans, in Romania, in southern Hungary, in Spain (up to the Ebro River), and in Portugal"' (my translation). It also has been found in the central Sahara of Algeria, near the Tropic of Cancer (Kiefer, 1958a,b) and in

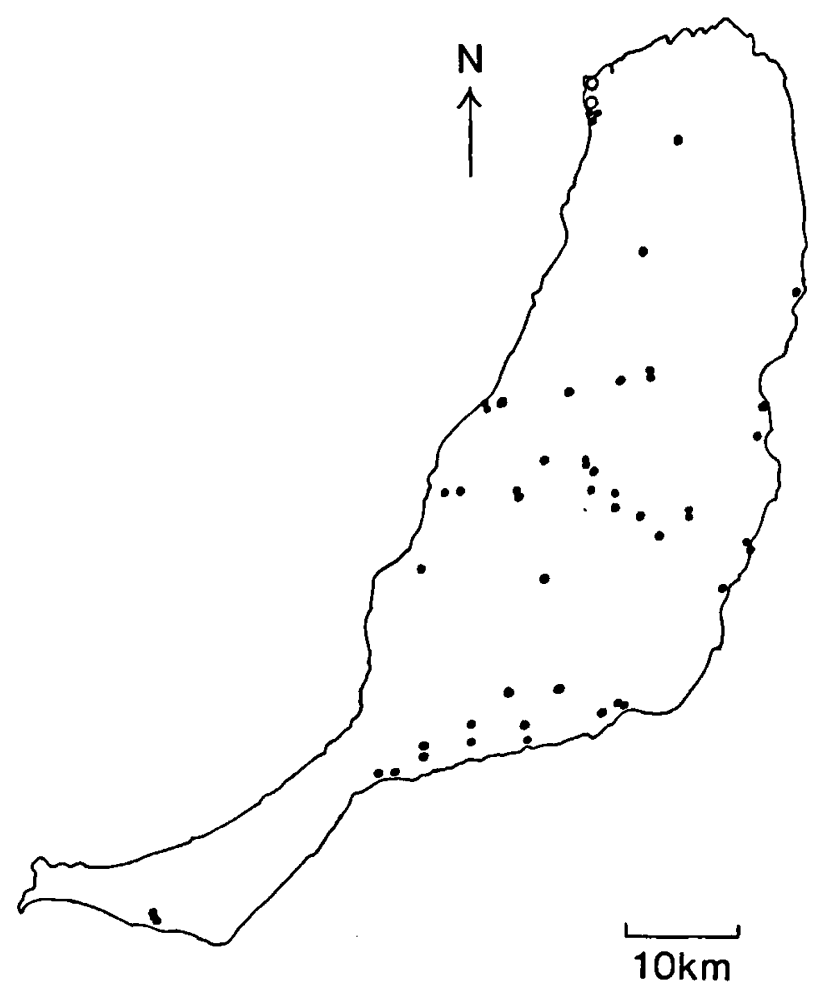

Fig. 2. Fuerteventura, showing locations of groundwater samples collected in 1985: Open circles, samples containing Lovenula (Neolovenula) alluaudi. Solid circles, other samples.

the Ennedi Mountains of northeast Chad (Dussart, 1968). A map showing its known distribution is given by Kiefer (1958a). The type-locality on Lanzarote, shown in Fig. 1, is a freshwater reservoir in Teguise (Guerne \& Richard, 1890).

Subsequent to the 1955 survey, in $1986 / 87$ hundreds of groundwater samples were collected in most of the other Canary Islands, but not a single calanoid was found in them. Evidently $L$. (N.) alluaudi occurs only on the eastern group of islands ("Purpuraria") and is not found on the western islands ("Macaronesia"). This distribution supports the proposition, discussed by Stock \& Broekhuizen (1986), that the eastern islands are fragments of the African continental plate, whereas the western islands arose de novo from the oceanic crust by volcanic activity. Lovenula must have inhabited the East Canaries block before its detachment. Separation may have occurred during the initial rifting between North America and Africa in the mid-Trias- 
Table I. Sex ratios of Lovenula (Neolovenula) alluaudi in the Canary Islands

\begin{tabular}{|c|c|c|}
\hline \multicolumn{3}{|l|}{ Lanzarote } \\
\hline $85-66$ & 1 & 100 \\
\hline $85-68$ & 4 & 75 \\
\hline $85-69$ & 2 & 50 \\
\hline $85-70$ & 3 & 0 \\
\hline $85-71$ & 5 & 60 \\
\hline $85-74$ & 1 & 100 \\
\hline \multirow[t]{2}{*}{$85-88$} & 392 & 82 \\
\hline & 119 & 85 \\
\hline $85-89$ & 137 & 85 \\
\hline $85-90$ & 41 & 90 \\
\hline $85-91$ & 11 & 100 \\
\hline $85-92$ & 9 & 78 \\
\hline $85-93$ & 15 & 80 \\
\hline $85-94$ & 4 & 75 \\
\hline $85-140$ & 2 & 50 \\
\hline $85-143$ & 14 & 36 \\
\hline $85-144$ & 10 & 50 \\
\hline $85-145$ & 6 & 67 \\
\hline $85-146$ & 83 & 43 \\
\hline $85-147$ & 46 & 48 \\
\hline $85-149$ & 17 & 59 \\
\hline $85-150$ & 11 & 27 \\
\hline \multicolumn{3}{|c|}{ Fuerteventura } \\
\hline $85-267$ & 6 & 100 \\
\hline $85-268$ & 15 & 80 \\
\hline \multicolumn{3}{|l|}{ Alegranza } \\
\hline $85-583$ & 80 & 31 \\
\hline
\end{tabular}

sic, or more probably in the early Cenozoic (Dietz \& Sproll, 1970).

An unexpected finding was the high proportion of males in the samples, summarized in Table $I$. Males outnumbered females in 14 samples, females were more numerous in 5 . In large samples $(\mathrm{N}>$ 40), males made up an average of $85.5 \%$ in the 4 samples in which they predominated. In the 2 samples with more females, the males averaged
$45.5 \%$. This preponderance of males is surprising because in most populations of calanoids the numbers of females equal or surpass, sometimes greatly, the numbers of males. A possible explanation is that in the groundwaters sampled via the wells that reached them, males do not predominate, but in search of mates they swim more actively than the females and thereby enter the wells in greater numbers.

\section{Acknowledgments}

I am grateful to Prof. Jan H. Stock for offering this interesting collection to me for study, and for allowing the Smithsonian Institution to retain a sample for its permanent collections.

\section{References}

Dietz, R.S. \& W.P. Sproll, 1970. East Canary Islands as a microcontinent within the Africa-North America continental drift fit. Nature, 226: 1043-1045.

Dussart, B., 1967. Les Copépodes des eaux continentales d'Europe occidentale. Tome I: Calanoïdes et Harpacticoïdes: 1-500 (N. Boubée \& Cie, Paris).

Dussart, B., 1968. Contribution à l'étude des eaux douces de l'Ennedi, I. Copépodes. Bull. I. F. A. N., (A) 30(1): 127-134.

Guerne, J. de \& J. Richard, 1890. Description du Diaptomus alluaudi n. sp. recueilli par M. Alluaud dans un réservoir d'eau douce à Lanzarotte (Canaries). Bull. Soc. zool. France, 15: 198-200.

Kiefer, F., 1958a. Diaptomiden (Crustacea Copepoda) aus dem Gebiet von Tassili n'Ajjer (Zentral-Sahara). Trav. Inst. Rech. Sahariennes (Série de Tassili, 3): 11-126.

Kiefer, F., 1958b. Über einige Diaptomiden (Crustacea Copepoda) aus der Zentralsahara. Zool. Anz., 160(7/8): 158-160.

Stock, J.H. \& B.L.M. Rondé-Broekhuizen. 1986. Stygofauna of the Canary Islands, 1. A new species of Pygocrangonyx, an amphipod genus with African affinities, from Fuerteventura. Bijdr. Dierk., 56(2): 247-266.

Received: 24 October 1989 